\title{
Impact of days post-burning and lime as an additive to reduce fermentative losses of burned sugarcane silages
}

\author{
Anna Paula T.P. Roth ${ }^{a, *}$, Gustavo R. Siqueira ${ }^{a, b}$, Carlos H.S. Rabelo $^{a}$, Carla J. \\ Härter $^{a}$, Fernanda C. Basso ${ }^{a}$, Telma T. Berchielli ${ }^{a}$, Ricardo A. Reis ${ }^{a}$ \\ a UNESP, Univ. Estadual Paulista, Department of Animal Sciences, Jaboticabal, 14884-900 SP, Brazil \\ b Agência Paulista de Tecnologia dos Agronegócios, Alta Mogiana, Colina, 14770-000 SP, Brazil
}

\section{A R T I C L E I N F O}

\section{Article history:}

Received 4 August 2015

Received in revised form 8 March 2016

Accepted 9 March 2016

\section{Keywords:}

Alkaline treatment

Burned silage

In natura silage

Yeast population

\begin{abstract}
A B S T R A C T
The objectives of our study were: 1 ) to investigate the effects of burning and the time elapsed between burning and ensiling on characteristics of sugarcane silages, and 2) to evaluate the effects of lime on fermentation and aerobic stability of in natura and burned sugarcane silages. In trial I, silages were prepared from burned sugarcane that remained in the field for varying number of days post-burning $(1,5,10,15,20,25$, and $30 \mathrm{~d})$. In trial II, the characteristics of burned and in natura sugarcane silages treated with various concentrations of lime $(0,5,10,15$, and $20 \mathrm{~g} / \mathrm{kg}$ of sugarcane, on an as-is fresh matter basis) were compared. In trial I, 10-d post-burning, sugarcane crop displayed great degrees brix $\left(18.3^{\circ} \mathrm{Bx}\right)$ and sucrose $(677.3 \mathrm{~g} / \mathrm{kg}$ of sugarcane broth) values. The yeast population in sugarcane crop 1-d post-burning ( $4.47 \mathrm{cfu} / \mathrm{g}$ of fresh forage) was lesser than that 25 -d postburning ( $7.11 \mathrm{cfu} / \mathrm{g}$ of fresh forage). After the silos were opened, all silages showed low $\mathrm{pH}$. The silage from 1-d post-burning had the least dry matter (DM) recovery ( $637.5 \mathrm{~g} / \mathrm{kg}$ of DM). The greatest DM recovery was found in the silage prepared 15-d post-burning $(740.0 \mathrm{~g} / \mathrm{kg})$. Silage from 20-d post-burning displayed the greatest aerobic stability ( $36.7 \mathrm{~h})$; however, in general, all silages had low aerobic stability $(<40 \mathrm{~h})$. In trial II, both the in natura and burned silages had reduced fiber content due to lime addition. Considering the overall mean, burned silages produced $47 \mathrm{~g}$ acetic acid $/ \mathrm{kg}$ of DM against $25.6 \mathrm{~g} / \mathrm{kg}$ of DM in in natura silages. Lime was more effective in increasing the production of acetic acid in in natura silages, but only when applied at great concentrations ( 15 and $20 \mathrm{~g} / \mathrm{kg}$ ). DM recovery of in natura silages decreased with increased addition of lime, whereas the opposite effect was observed for burned silages. In natura and burned silages treated with lime at 15 and $20 \mathrm{~g} / \mathrm{kg}$ had greater aerobic stability ( $>8 \mathrm{~d}$ ) than those treated with lesser quantities of lime. Considering the approach in which this study was carried out, a period of 10-15 days is ideal for ensilage of burned sugarcane prior to the silage quality significantly drops. Lime may be used as an additive for both in natura and burned silages since in greater levels (15 and $20 \mathrm{~g} / \mathrm{kg}$ ).
\end{abstract}

(c) 2016 Elsevier B.V. All rights reserved.

\footnotetext{
* Corresponding author.

E-mail address: annapaularoth@yahoo.com.br (A.P.T.P. Roth).
} 


\section{Introduction}

Sugarcane crops display great herbage production (25-40 t/ha of dry matter [DM]) and great energy values at maturity compared to other crops (Ávila et al., 2009); it is widely used as silage in diets for beef cattle and dairy cows in Brazil (Bernardes and Rêgo, 2014; Millen et al., 2009) because the difficult to perform daily cuts of fresh sugarcane on the field. Sugarcane is often harvested during the dry season. In this period, there is a great risk of accidental burning, which prevents the use of sugarcane in a direct cut system. Therefore, ensiling may be an effective strategy to avoid greater losses of quality and DM in this situation, but the maximum time that sugarcane can remain in the field post-burning before quality declines significantly is not conclusive (Roth et al., 2010).

Conversely, sugarcane ensiling may result in large DM losses $(>300 \mathrm{~g} / \mathrm{kg})$ during fermentation due to the conversion of sucrose to ethanol by yeast, leading to the reduction in silage nutritive value, aerobic stability, and feed intake by livestock (Kung and Stanley, 1982; Pedroso et al., 2005). Thus, the addition, of an alkaline agent (e.g., lime) at the farm level has been recommended for reducing the fungi population and increasing the growth of the lactic-acid bacteria (LAB) population (Cavali et al., 2010), as well as to increase DM recovery (Rabelo et al., 2014), and improve the sugarcane silage digestibility (Siqueira et al., 2007, 2011a). These treatment effects are relatively well known for in natura sugarcane silage, but few studies have evaluated the process of ensiling burned sugarcane or the effect of chemical additives on this process. In that few studies, lime addition increased the in vitro digestibility (Roth et al., 2010) and DM recovery of burned sugarcane silages (Siqueira et al., 2011a).

Therefore, our objectives were to investigate the effects of the time between burning and ensiling on sugarcane silage characteristics and the effect of lime on fermentation and aerobic stability of in natura and burned sugarcane silages.

\section{Material and methods}

\subsection{Ensiling process}

\subsubsection{Trial I}

In trial I, we used a crop of the IAC 86-2480 sugarcane cultivar after 12 months of growth (third cut). The sugarcane field was burned at sunset on the day before cutting. The stems were not severed from their roots until harvest taking into consideration any incidence of accidental fire.

On days $1,5,10,15,20,25$, and 30 post-burning, sugarcane was mechanically harvested using an ensilager (Menta Mit, ColhiFlex model, Cajuru, SP, Brazil). Mini-silos (plastic buckets of $7 \mathrm{~L}$ capacity) were used in quadruplicate for ensiling, which were closed with plastic lids and sealed with adhesive tape; a density of $676 \mathrm{~kg}$ fresh matter $/ \mathrm{m}^{3}$ was obtained.

\subsubsection{Trial II}

The sugarcane used in trial II was similar to that used in trial I. The sugarcane field was burned at sunset the day before cutting, and 1-d post-burning sugarcane was used to ensilage. After harvest, the burned and in natura sugarcane either remained untreated or was treated with lime (micro-pulverized calcium oxide) at $5,10,15$, and $20 \mathrm{~g} / \mathrm{kg}$ (on an as-is fresh matter basis). Lime was diluted in water at a ratio of $1.0 \mathrm{~kg}$ lime per $4 \mathrm{~L}$ of water and applied at $20,40,60$, and $80 \mathrm{~mL} / \mathrm{kg}$ of fresh sugarcane to obtain the concentrations described earlier. Lime was then well-mixed with the sugarcane multiple times to ensure good homogenization.

Mini-silos (plastic buckets of 20 L capacity) were used in quadruplicate for ensiling, and were closed with a plastic lid and sealed using adhesive tape; a density of 872 and $562 \mathrm{~kg}$ fresh matter $/ \mathrm{m}^{3}$ was obtained for burned and in natura sugarcane, respectively.

\subsection{Fermentative losses}

In both trials, the mini-silos were weighed immediately upon ensiling and after opening at the end of the ensiling period (56 d) to determine gas and DM losses, which were calculated as:

$$
\text { Gaslosses }(\mathrm{g} / \text { kgofDM })=\left(\left(\left(\mathrm{F}_{\mathrm{en}} \times \mathrm{DM}_{\mathrm{en}}\right)-\left(\mathrm{F}_{\mathrm{op}} \times \mathrm{DM}_{\mathrm{op}}\right)\right) /\left(\mathrm{F}_{\mathrm{en}} \times \mathrm{DM}_{\mathrm{en}}\right)\right) \times 100
$$

where $\mathrm{F}_{\mathrm{op}}$ and $\mathrm{DM}_{\mathrm{op}}=$ forage mass and DM content of the silos at opening, respectively; $\mathrm{F}_{\mathrm{en}}$ and $\mathrm{DM} \mathrm{M}_{\mathrm{en}}=$ forage mass and DM content at ensiling, respectively.

$$
\text { DMrecovery }(\mathrm{g} / \mathrm{kg})=\left(\mathrm{F}_{\mathrm{op}} \times \mathrm{DM}_{\mathrm{op}}\right) /\left(\mathrm{F}_{\mathrm{en}} \times \mathrm{DM}_{\mathrm{en}}\right) \times 100
$$

where $\mathrm{F}_{\mathrm{op}}$ and $\mathrm{DM}_{\mathrm{op}}=$ forage mass and DM content of the silos at opening, respectively; $\mathrm{F}_{\mathrm{en}}$ and $\mathrm{DM} \mathrm{M}_{\mathrm{en}}=$ forage mass and DM content at ensiling, respectively.

\subsection{Aerobic stability}

To determine aerobic stability, a silage sample from each mini-silo was placed in a plastic bucket of $7 \mathrm{~L}$ capacity and kept at ambient temperature. A data logger was placed in the silage and the silage temperature was measured every hour for 9 
$\mathrm{d}$. The ambient temperature was measured using data loggers placed close to the mini-silos. Aerobic stability was defined as the number of hours that the silage temperature remains stable before increasing more than $2^{\circ} \mathrm{C}$ above the ambient temperature (Moran et al., 1996). Additionally, the sum of accumulated daily temperatures was calculated as the sum of the difference between the silage and ambient temperatures after 5 and $9 \mathrm{~d}$ (SUM 5 and SUM 9) of aerobic exposure (O'Kiely, 1999). The heating rate was calculated as the maximum recorded temperature divided by the time required reaching the maximum temperature (Ruppel et al., 1995). The $\mathrm{pH}$ values were recorded at the initial time (day 0), and after 3, 6, and $9 \mathrm{~d}$ of aerobic exposure.

\subsection{In vitro gas production and digestibility}

Animal care and handling procedures used in this study were approved by the Sao Paulo State University's Animal Care Committee, in agreement with the guidelines of the Brazilian National Council for the Control of Animal Experimentation (CONCEA).

Dried silage samples $(0.2 \mathrm{~g})$ were placed in $115-\mathrm{mL}$ serum bottles and incubated in a water bath at $39^{\circ} \mathrm{C}$ (Mauricio et al., 1999) with a rumen inoculum and buffer solution in a ratio of $4: 1$ (30 mL for each bottle) for $144 \mathrm{~h}$. Prior to incubation, $\mathrm{CO}_{2}$ was continuously purged for $30 \mathrm{~min}$, and the reducing solution was added to the ruminal fluid. The bottles ( 4 for each treatment) were then sealed with a rubber stopper plus an aluminum crimp cap and stored in a water bath $\left(39{ }^{\circ} \mathrm{C}\right.$ ). For the buffer solution, we used the Kansas State "synthetic saliva" (Marten and Barnes, 1979), which was adapted from the two-stage technique of Tilley and Terry (1963). The ruminal fluid was collected from 2 rumen-cannulated sheep in the morning before feeding. The animals were fed $600 \mathrm{~g} / \mathrm{kg}$ sugarcane silage treated with lime at $10 \mathrm{~g} / \mathrm{kg}$ and $400 \mathrm{~g} / \mathrm{kg}$ concentrate composed of ground corn, soybean meal and urea, on a DM basis. The rumen fluid was filtered through 4 layers of cheesecloth into pre-warmed thermos flasks, homogenized, and mixed with the buffer solution.

The accumulated headspace gas pressure was measured using a needle attached to a pressure transducer connected to a visual display (Datalogger pressure- pressDATA 800, MPL, Piracicaba, SP, Brazil). Readings were taken at regular intervals throughout the incubation period and at an increased frequency during the initial lag and rapid fermentation phases (i.e., $2,4,6,8,10,12,16,20,24,28,32,36,48,52,56,60,72,78,84,96,108,120,132$, and $144 \mathrm{~h})$. To correct changes in the atmospheric pressure, two flasks were incubated without samples (blank) (Pell and Schofield, 1993). The volume of gas in the blanks was subtracted from the reading of gas volume to obtain the true sample gas volume.

Since in vitro gas production is mostly due to digestible carbohydrate content, rather than that of protein and fat, we used a multiple regression analysis (Menke and Steingass, 1988) to calculate the digestible organic matter (IVOMD):

$$
\operatorname{IVOMD}(\mathrm{g} / \mathrm{kg})=14.88+(0.889 \times \text { gas } 24)+(0.045 \times \mathrm{CP})+(0.065 \times \text { Ash })
$$

where gas $24=$ gas production after $24 \mathrm{~h}(\mathrm{~mL} / 0.2 \mathrm{~g}$ of DM) and crude protein (CP) and ash contents are expressed as $\mathrm{g} / \mathrm{kg}$ of DM.

\subsection{Chemical analyses}

One sample of forage and silage from each mini-silo was used for the chemical analyses. Each sample was divided into three sub-samples. The first sub-sample was weighed and placed in a forced air chamber at $55^{\circ} \mathrm{C}$ for $72 \mathrm{~h}$. After this period, these sub-samples were again weighed, ground in a knife grinder until the particle size reduced to less than $1 \mathrm{~mm}$, and stored in plastic pots for determination of DM $\left(105^{\circ} \mathrm{C}\right.$ for $\left.12 \mathrm{~h}\right)$ and ash $\left(500^{\circ} \mathrm{C}\right.$ for $\left.5 \mathrm{~h}\right)$. CP was determined following the methodology recommended by AOAC (1996), method no. 960.52). Neutral detergent fiber (NDF) and acid detergent fiber (ADF) were determined by the sequential method (Robertson and Van Soest, 1981). The NDF was assayed without a heat stable amylase, and NDF and ADF were expressed inclusive of residual ash. Cellulose was measured after hydrolysis in ADF residues in $72 \% \mathrm{H}_{2} \mathrm{SO}_{4}$ (Van Soest, 1994), and lignin (sa) content was calculated as the difference between ADF and cellulose.

The second sub-sample was used to prepare a water extract (Kung et al., 1984) and pH was measured using an electrode (model MA522, Marconi Laboratory Equipment, Piracicaba, Sao Paulo, Brazil). Acetic acid was measured using a gas chromatograph (Shimadzu model GC2014, Shimadzu Corp., Kyoto, Japan) equipped with a HP-INNOWax capillary column $\left(30 \mathrm{~m} \times 0.32 \mathrm{~mm}\right.$; Agilent Technologies, Colorado, USA) at an initial temperature of $80^{\circ} \mathrm{C}$ for $3 \mathrm{~min}$ followed by a heating rate of $20^{\circ} \mathrm{C} / \mathrm{min}$ until a final temperature of $240^{\circ} \mathrm{C}$ was achieved. The amount of total soluble solids (Brix), sucrose content, redox sugars (glucose + fructose), and purity of sugarcane broth also were measured (Bovi and Serra, 1999).

The third sub-sample was used for microbiological analyses performed according to Kurtman and Fell (1998). Briefly, a $25 \mathrm{~g}$ silage sample from each replicate was homogenized in $225 \mathrm{~mL}$ of saline solution $(0.85 \% \mathrm{NaCl})$ for $1 \mathrm{~min}$. Then $1 \mathrm{~mL}$ of this solution was transferred into tubes with $9 \mathrm{~mL}$ of saline solution, from which $0.1-\mathrm{mL}$ samples were transferred to Petri plates at dilutions from $10^{-1}$ to $10^{-5}$. Potato dextrose agar (PDA) was used as a medium to cultivate yeasts. The plates with PDA were kept at $28^{\circ} \mathrm{C}$ for $72 \mathrm{~h}$. Microbiological data were log-transformed for statistical analysis.

\subsection{Statistical analyses}

Both experiments were performed using a completely randomized design with four replicates. Data from fermentation and aerobic stability were analyzed with a mixed model using the MIXED procedure of SAS (v 9.4, SAS Inst. Inc., Cary), 
Table 1

Chemical composition ( $\mathrm{g} / \mathrm{kg}$ of DM, unless otherwise stated) of sugarcane at different days post-burning and before ensiling.

\begin{tabular}{|c|c|c|c|c|c|c|c|c|c|c|}
\hline \multirow[t]{2}{*}{ Item $^{a}$} & \multicolumn{7}{|c|}{ Days post burning } & \multirow[t]{2}{*}{ SEM } & \multirow[t]{2}{*}{ P-value } & \multirow[t]{2}{*}{ Contrast $^{b}$} \\
\hline & 1 & 5 & 10 & 15 & 20 & 25 & 30 & & & \\
\hline DM, g/kg as fed & 270.4 & 268.4 & 241.2 & 256.7 & 242.9 & 242.0 & 255.3 & 3.94 & \multicolumn{2}{|c|}{$<0.0001 \mathrm{Q}^{* *}$} \\
\hline Ash & 15.3 & 20.3 & 14.3 & 16.3 & 33.1 & 28.4 & 16.0 & 1.16 & $<0.0001$ & $C^{* *}$ \\
\hline $\mathrm{CP}$ & 29.9 & 29.0 & 27.3 & 28.8 & 30.0 & 29.0 & 30.6 & 0.50 & 0.0031 & $Q^{*}$ \\
\hline NDF & 413.7 & 430.0 & 405.6 & 433.8 & 491.8 & 464.2 & 469.2 & 8.41 & $<0.0001$ & $Q^{*}$ \\
\hline $\mathrm{ADF}$ & 248.7 & 262.5 & 255.4 & 272.3 & 318.3 & 294.9 & 294.5 & 7.31 & $<0.0001$ & $\mathrm{Q}^{*}$ \\
\hline Lignin (sa) & 38.5 & 40.5 & 38.5 & 44.7 & 78.3 & 53.3 & 47.4 & 3.39 & $<0.0001$ & $\mathrm{Q}^{* *}$ \\
\hline IVOMD & 545.7 & 539.1 & 540.1 & 554.1 & 555.7 & 538.9 & 559.6 & 8.48 & 0.4371 & NS \\
\hline Brix, ${ }^{\circ}$ & 17.1 & 18.2 & 18.3 & 16.8 & 17.1 & 18.1 & 17.9 & 0.11 & $<0.0001$ & $C^{* *}$ \\
\hline Sucrose, $\mathrm{g} / \mathrm{kg}$ of sugarcane broth & 602.2 & 661.7 & 677.3 & 565.7 & 570.8 & 562.4 & 549.4 & 6.41 & $<0.0001$ & $\mathrm{C}^{* *}$ \\
\hline Pooled sugars, $\mathrm{g} / \mathrm{kg}$ of sugarcane broth & 147.7 & 161.6 & 165.2 & 139.2 & 140.1 & 137.4 & 134.4 & 1.54 & $<0.0001$ & $C^{* *}$ \\
\hline Redox sugar, g/kg of sugarcane broth & 6.8 & 5.9 & 5.7 & 8.0 & 8.3 & 10.4 & 10.6 & 0.29 & $<0.0001$ & $C^{* *}$ \\
\hline Purity, $\mathrm{g} / \mathrm{kg}$ of total sugars & 863.0 & 888.4 & 894.8 & 826.2 & 821.2 & 758.7 & 751.4 & 8.33 & $<0.0001$ & $\mathrm{C}^{* *}$ \\
\hline Yeasts, $\log \mathrm{cfu} / \mathrm{g}$ & 4.47 & 5.20 & 5.36 & 5.28 & 5.79 & 7.11 & 6.14 & 0.09 & $<0.0001$ & $\mathrm{C}^{*}$ \\
\hline
\end{tabular}

a $\mathrm{DM}=$ dry matter; $\mathrm{CP}=$ crude protein; $\mathrm{NDF}=$ neutral detergent fiber; $\mathrm{ADF}=$ acid detergent fiber; $\mathrm{IVOMD}=$ in vitro organic matter digestibility.

b NS= no significant; $Q=$ quadratic effect; $C=$ cubic effect.

* $\mathrm{P}<0.05$.

** $\mathrm{P}<0.01$.

factoring in the number of days that sugarcane remained in the field post-burning (trial I), silage type (in natura or burned) and lime levels (trial II) as fixed effects, and the residual error as a random effect. The following general models were used:

Trial I

$$
Y_{i j}=\mu+D_{i}+e_{i j}
$$

where $Y_{i j}=$ response variable; $\mu=$ overall mean; $D=$ effect of ensiling in different post-burning days $i$; and $e_{i j}=$ error term.

Trial II

$$
Y_{i j k}=\mu+S_{i}+L_{j}+S L_{i j}+e_{i j k}
$$

where $Y_{i j k}=$ response variable; $\mu$ overall mean; $S=$ effect of silage type (in natura or burned) $i ; L=$ effect of lime levels $j$; $S L=$ effect of the interaction between silage type $i$ and lime levels $j$; and $e_{i j k}=$ error term.

Differences between means were determined using the DIFF option of the LSMEANS statement, which differentiates means based on Fisher's F-protected least significant difference test. Contrasts were constructed, and the single degreeof-freedom orthogonal comparisons included the linear, quadratic, and cubic effects of ensiling on different numbers of post-burning days (trial I) and lime levels (trial II). For both trials, quartic effects were studied; however, we did not use this effect even when was it significant because a biological explanation would be difficult and likely would not make much sense. When there was significant interaction between the factors studied in trial II, contrasts were constructed based on that interaction. Differences were declared significant at $\mathrm{P} \leq 0.05$.

The $\mathrm{pH}$ values over aerobic exposure time were analyzed as a completely randomized design with repeated measures over time. The covariance matrix that best fit the data according to the Bayesian information criterion (BIC) was selected to perform the analysis. The following general models were used:

Trial I

$$
Y_{i j k}=\mu+D_{i}+T_{j}+D T_{i j}+e_{i j k}
$$

where $Y_{i j k}=$ response variable; $\mu$ = overall mean; $D=$ effect of ensiling on post-burning day $i$; $T=$ effect of aerobic exposure time $j$; $D T=$ effect of interaction between ensiling on post-burning day $i$ and aerobic exposure time $j$; and $e_{i j k}=\operatorname{error}$ term.

Trial II

$$
Y_{i j k l}=\mu+S_{i}+L_{j}+S L_{i j}+T_{k}+S T_{i k}+L T_{j k}+S L T_{i j k}+e_{i j k l}
$$

where $Y_{i j k l}=$ response variable; $\mu$ overall mean; $S=$ effect of silage type (in natura or burned) $i$; $L=$ effect of lime levels $j$; $S L=$ effect of interaction between silage type $i$ and lime levels $j ; T=$ effect of aerobic exposure time $k$; $S T=$ effect of interaction between silage type $i$ and aerobic exposure time $k ; L T=$ effect of interaction between lime levels $j$ and aerobic exposure time $k ; S L T=$ effect of interaction among silage type $i$, lime levels $j$ and aerobic exposure time $k$; and $e_{i j k l}=$ error term. 
Table 2

Chemical composition, fermentation, and aerobic stability of sugarcane silages prepared 1-20 days post burning.

\begin{tabular}{|c|c|c|c|c|c|c|c|c|c|c|}
\hline \multirow[t]{2}{*}{ Item $^{\mathrm{a}}$} & \multicolumn{7}{|c|}{ Days post burning } & \multirow[t]{2}{*}{ SEM } & \multirow[t]{2}{*}{ P-value } & \multirow[t]{2}{*}{ Contrast $^{\mathrm{b}}$} \\
\hline & 1 & 5 & 10 & 15 & 20 & 25 & 30 & & & \\
\hline \multicolumn{11}{|c|}{ Chemical composition, $\mathrm{g} / \mathrm{kg}$ of DM } \\
\hline DM, g/kg as fed & 162.5 & 168.5 & 165.2 & 179.7 & 168.7 & 180.8 & 171.2 & 2.50 & 0.0008 & $Q^{*}$ \\
\hline Ash & 25.3 & 24.2 & 21.3 & 20.5 & 35.4 & 32.0 & 24.4 & 1.29 & $<0.0001$ & $C^{* *}$ \\
\hline $\mathrm{CP}$ & 45.2 & 40.4 & 41.8 & 41.1 & 44.7 & 42.9 & 49.2 & 0.77 & $<0.0001$ & $\mathrm{Q}^{* *}$ \\
\hline NDF & 704.4 & 679.7 & 633.5 & 605.9 & 728.3 & 704.7 & 742.3 & 13.41 & $<0.0001$ & $C^{*}$ \\
\hline ADF & 434.1 & 425.8 & 412.3 & 392.6 & 477.1 & 469.5 & 473.8 & 11.21 & 0.0002 & $\mathrm{C}^{*}$ \\
\hline Lignin (sa) & 70.5 & 79.0 & 73.2 & 64.6 & 96.5 & 96.4 & 86.8 & 5.35 & 0.0021 & $\mathrm{~L}^{*}$ \\
\hline IVOMD & 485.2 & 488.2 & 490.4 & 478.0 & 472.5 & 458.4 & 437.7 & 5.39 & $<0.0001$ & $Q^{*}$ \\
\hline \multicolumn{11}{|c|}{ Fermentation process, $\mathrm{g} / \mathrm{kg}$ of DM } \\
\hline Acetic acid & 133.7 & 39.0 & 31.9 & 35.4 & 71.8 & 90.1 & 127.3 & 21.60 & 0.0034 & $\mathrm{Q}^{*}$ \\
\hline $\mathrm{pH}$ & 3.26 & 3.26 & 3.33 & 3.41 & 3.27 & 3.29 & 3.16 & 0.03 & 0.0003 & $\mathrm{Q}^{* *}$ \\
\hline Gas losses & 361.4 & 328.2 & 289.5 & 259.1 & 338.9 & 323.9 & 329.9 & 6.59 & 0.0047 & $\mathrm{C}^{*}$ \\
\hline DM recovery & 637.5 & 670.6 & 709.4 & 740.0 & 660.2 & 675.4 & 669.2 & 15.88 & 0.0047 & $C^{*}$ \\
\hline \multicolumn{11}{|l|}{ Aerobic exposure } \\
\hline Initial $\mathrm{T},{ }^{\circ} \mathrm{C}$ & 28.3 & 28.2 & 27.9 & 28.1 & 28.0 & 28.1 & 28.1 & 0.18 & 0.8191 & NS \\
\hline Maximum $\mathrm{T},{ }^{\circ} \mathrm{C}$ & 44.8 & 42.4 & 44.1 & 46.0 & 42.1 & 43.1 & 43.3 & 0.39 & $<0.0001$ & $\mathrm{~L}^{*}$ \\
\hline Heating rate, ${ }^{\circ} \mathrm{C} / \mathrm{h}$ & 0.60 & 0.30 & 0.43 & 0.56 & 0.15 & 0.52 & 0.28 & 0.07 & 0.0009 & $\mathrm{~L}^{*}$ \\
\hline SUM $5,{ }^{\circ} \mathrm{C}^{\mathrm{c}}$ & 24.9 & 26.3 & 24.1 & 27.9 & 21.0 & 26.0 & 24.0 & 1.78 & 0.1846 & NS \\
\hline SUM $9,{ }^{\circ} \mathrm{C}^{\mathrm{c}}$ & 38.2 & 40.5 & 43.1 & 42.6 & 42.4 & 37.0 & 32.0 & 3.52 & 0.4207 & NS \\
\hline Aerobic stability, h & 14.7 & 33.3 & 34.8 & 29.5 & 36.7 & 21.0 & 33.0 & 2.29 & $<0.0001$ & $\mathrm{C}^{* *}$ \\
\hline
\end{tabular}

a $\mathrm{DM}=$ dry matter; $\mathrm{CP}=$ crude protein; $\mathrm{NDF}=$ neutral detergent fiber; $\mathrm{ADF}=$ acid detergent fiber; $\mathrm{IVOMD}=$ in vitro organic matter digestibility

b $\mathrm{NS}=$ no significant; $\mathrm{L}=$ linear effect; $\mathrm{Q}=$ quadratic effect; $\mathrm{C}=$ cubic effect.

c Sum of the difference of temperatures between silages and ambient after 5 and $9 \mathrm{~d}$ of aerobic exposure.

* $\mathrm{P}<0.05$.

** $\mathrm{P}<0.01$.

\section{Results}

\subsection{Trial I}

\subsubsection{Characteristics of sugarcane post-burning}

All variables were affected by the number of days post-burning, except the coefficients of IVOMD (P >0.05; Table 1). The DM content had a quadratic response, and the greatest $(\mathrm{P}<0.01)$ value was observed $1-\mathrm{d}$ post-burning. Ash content had a large range during the evaluated times, and the least and greatest values $(\mathrm{P}<0.01)$ were found 10 - and 20 -d post-burning, respectively. A quadratic response was observed for $C P$, and the greatest content $(P<0.01)$ was observed 30-d post-burning. The NDF, ADF, and lignin contents showed a quadratic response; the least values $(\mathrm{P}<0.01)$ were found between 1 - and $10-\mathrm{d}$ post-burning.

All characteristics associated with sugars showed cubic responses (Table 1); the values of brix, sucrose, pooled (total) sugars, and purity were greatest $(\mathrm{P}<0.01)$ for 10 -d post-burning, whereas at this time the redox sugar had its least value. There was a large range (cubic response) in yeast populations, and the least value $(\mathrm{P}<0.01)$ was observed 1-d post-burning $(4.47 \mathrm{cfu} / \mathrm{g}$ of burned sugarcane), whereas the greatest value $(7.11 \mathrm{cfu} / \mathrm{g}$ of burned sugarcane) was observed $25-\mathrm{d}$ postburning.

\subsubsection{Chemical composition and fermentation profile of burned sugarcane silages}

All variables were affected by the time between burning and ensiling (Table 2). DM content exhibited a quadratic response, where the greatest value $(\mathrm{P}<0.01)$ was obtained $25-\mathrm{d}$ post-burning. Ash also showed a large range, and the greatest value $(\mathrm{P}<0.01)$ was found 20-d post-burning. CP showed a quadratic response, and the silage prepared 30-d post-burning exhibited the greatest content $(\mathrm{P}<0.01)$. Considering overall means, burned sugarcane silages showed an increase in $\mathrm{CP}(43.6 \mathrm{~g} / \mathrm{kg}$ of DM) compared with the material prior to ensiling $(29.2 \mathrm{~g} / \mathrm{kg}$ of DM). Lesser quantities of NDF, ADF, and lignin were found $15-d$ post-burning $(P<0.01)$. Despite the quadratic response, the coefficients of IVOMD were greater $(P<0.01)$ on $1-, 5-$, and 10-d post-burning.

In the fermentation profile, acetic acid showed a quadratic response, and the greatest values $(\mathrm{P}<0.01)$ were found in 1 and 30-d post-burning silages (Table 2). Comparison of the means of the 1-and 30-d silages with the means of the other silages revealed that the production of acetic acid was greater in the 1 - and $30-\mathrm{d}$ silages (130.5 g/kg of DM) than in other silages $(53.6 \mathrm{~g} / \mathrm{kg}$ of $\mathrm{DM})$. The least $\mathrm{pH}$ value was obtained in the $30-\mathrm{d}$ post-burning silage $(\mathrm{P}<0.01)$; however, this value was remarkably low for all silages regardless of the number of post-burning days. Silage prepared 1-d post-burning had the greatest $(\mathrm{P}<0.01)$ gas losses and least $(\mathrm{P}<0.01) \mathrm{DM}$ recovery $(361.4$ and $637.5 \mathrm{~g} / \mathrm{kg}$ of DM). The least gas losses and greatest DM recovery was observed in 15-d post-burning silage (reduction of $29.5 \mathrm{~g} / \mathrm{kg}$ of DM on gas losses and increment of $102.5 \mathrm{~g} / \mathrm{kg}$ of DM on DM recovery compared to 1 -d silage). 


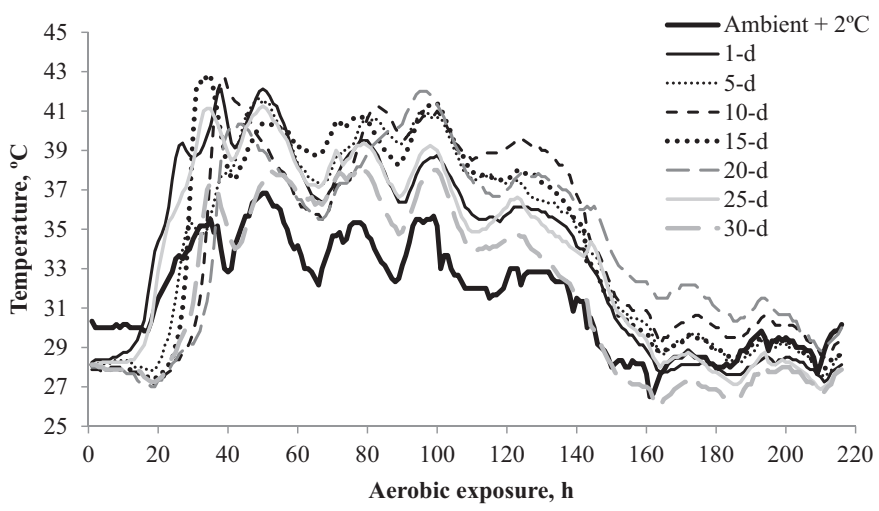

Fig. 1. Temperature of burned sugarcane silages prepared in different days post burning during aerobic exposure.

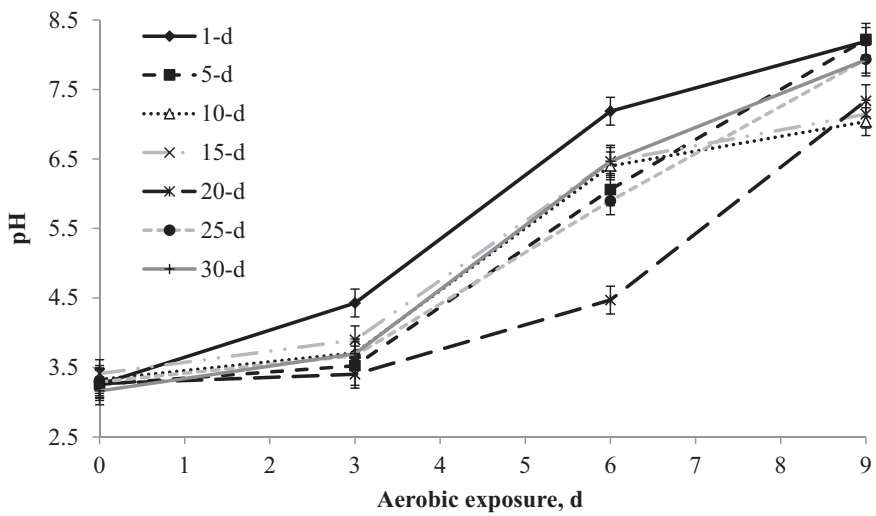

Fig. 2. $\mathrm{pH}$ values of burned sugarcane silages during aerobic exposure (effect of days post burning: $\mathrm{P}<0.01$; aerobic exposure days: $\mathrm{P}<0.01$; interaction between the factors: $\mathrm{P}<0.01$ ).

\subsubsection{Aerobic stability of burned sugarcane silages}

The initial temperature and sum of the differences between silage and ambient temperatures after 5 and $10 \mathrm{~d}$ of aerobic exposure were unaffected $(\mathrm{P}>0.05)$ by treatments (Table 2$)$. However, the 20-d post-burning silage had the least maximum temperature and heating rate $(\mathrm{P}<0.01)$, as well as the greatest $(\mathrm{P}<0.01)$ aerobic stability. All silages lost aerobic stability quickly and had temperatures at least $2^{\circ} \mathrm{C}$ above the ambient temperature after $35 \mathrm{~h}$ of aerobic exposure (Fig. 1).

An interaction $(\mathrm{P}<0.01)$ between the time before ensiling and the number of aerobic exposure days was observed for $\mathrm{pH}$ values (Fig. 2). Until $6 \mathrm{~d}$ after the silos were opened, the 20-d post-burning silage had the least $\mathrm{pH}$ values, which is consistent with the greater aerobic stability observed in this silage. However, after $9 \mathrm{~d}$ of aerobic exposure, the least pH value was found in $10-d$ post-burning silage.

\subsection{Trial II}

\subsubsection{In natura and burned sugarcane treated with different lime levels prior to ensiling}

Interactions $(\mathrm{P}<0.01)$ between forage type (in natura and burned) and lime levels for DM, ash, CP, NDF, and ADF contents were observed (Table 3 ). As expected, in natura sugarcane had greater $(\mathrm{P}<0.01)$ DM content than burned sugarcane. However, lime decreased the DM when applied to in natura sugarcane. For burned sugarcane, silages treated with 15 and $20 \mathrm{~g} / \mathrm{kg}$ of lime had greater DM content than those treated with 5 and $10 \mathrm{~g} / \mathrm{kg}$. Conversely, the ash content quadratically increased with increased lime addition, and the greatest value was found in in natura sugarcane treated with $20 \mathrm{~g} / \mathrm{kg}$ of lime.

Overall, CP content quadratically decreased due to the addition of lime (Table 3). For in natura sugarcane, the reduction in $\mathrm{CP}$ was $4.1 \mathrm{~g} / \mathrm{kg}$ of DM compared to untreated sugarcane and that treated with $20 \mathrm{~g} / \mathrm{kg}$ of lime $(29.2 \mathrm{~g} / \mathrm{kg}$ of DM). A greater CP reduction $(5.8 \mathrm{~g} / \mathrm{kg}$ of DM) was observed for burned sugarcane compared to sugarcane untreated and treated with $10 \mathrm{~g} / \mathrm{kg}$ of lime.

Lime quadratically reduced the NDF content in both sugarcanes (Table 3). A reduction of $136.2 \mathrm{~g} \mathrm{NDF} / \mathrm{kg}$ of DM was found for in natura sugarcane when treated with $20 \mathrm{~g} / \mathrm{kg}$ of lime compared to untreated forage. The burned sugarcane treated with $10 \mathrm{~g} / \mathrm{kg}$ had $42.2 \mathrm{~g} \mathrm{NDF} / \mathrm{kg}$ of DM less compared to untreated burned sugarcane. Application of $20 \mathrm{~g} / \mathrm{kg}$ lime quadratically 
Table 3

Chemical composition ( $\mathrm{g} / \mathrm{kg}$ of DM) of in natura and burned sugarcane either untreated or treated with lime (g/kg of sugarcane, on an as-is fresh matter basis) before ensiling.

\begin{tabular}{|c|c|c|c|c|c|c|c|c|c|c|c|c|c|c|c|}
\hline \multirow[t]{2}{*}{ Item $^{1}$} & \multicolumn{5}{|c|}{ In natura } & \multicolumn{5}{|l|}{ Burned } & \multicolumn{4}{|c|}{ SEM P-value ${ }^{2}$} & \multirow{2}{*}{$\frac{\text { Contrast }^{3}}{\text { Main Interaction }}$} \\
\hline & 0 & 5 & 10 & 15 & 20 & 0 & 5 & 10 & 15 & 20 & & $\mathrm{~S}$ & $\mathrm{~L}$ & $\mathrm{~S} \times \mathrm{L}$ & \\
\hline $\mathrm{DM}, \mathrm{g} / \mathrm{kg}$ as fed & $327.8^{a}$ & $321.0^{\mathrm{ab}}$ & $313.9^{b c}$ & $309.9^{\mathrm{cd}}$ & $303.4^{\mathrm{d}}$ & $260.8^{\mathrm{ef}}$ & $256.1^{f}$ & $256.2^{f}$ & $265.7^{\mathrm{e}}$ & $266.4^{\mathrm{e}}$ & 3.04 & $<0.0001$ & 0.0417 & $<0.0001$ & $\mathrm{~L}^{* *}$ \\
\hline Ash & $28.2^{\mathrm{f}}$ & $42.9^{\mathrm{e}}$ & $64.8^{d}$ & $96.3^{\mathrm{b}}$ & $117.6^{\mathrm{a}}$ & $17.5^{g}$ & $46.5^{\mathrm{e}}$ & $73.9^{c}$ & $93.2^{\mathrm{b}}$ & $97.2^{\mathrm{b}}$ & 3.17 & 0.0938 & $<0.0001$ & $<0.0001$ & $\mathrm{Q}^{* * *}$ \\
\hline $\mathrm{CP}$ & $33.3^{\mathrm{ab}}$ & $34.5^{\mathrm{a}}$ & $34.0^{\mathrm{ab}}$ & $31.7^{\mathrm{b}}$ & $29.2^{c}$ & $29.2^{c}$ & $26.1^{\mathrm{d}}$ & $23.4^{\mathrm{e}}$ & $25.3^{\text {de }}$ & $26.2^{\mathrm{d}}$ & 0.76 & $<0.0001$ & 0.0007 & 0.0002 & $Q^{* *}$ \\
\hline NDF & $607.0^{\mathrm{a}}$ & $614.2^{\mathrm{a}}$ & $573.0^{\mathrm{b}}$ & $531.8^{c}$ & $470.8^{d}$ & $407.4^{\mathrm{e}}$ & $379.5^{\mathrm{fg}}$ & $365.2^{\mathrm{g}}$ & $392.7^{\text {ef }}$ & $397.2^{\mathrm{ef}}$ & 9.27 & $<0.0001$ & $<0.0001$ & $<0.0001$ & $\mathrm{Q}^{* *}$ \\
\hline ADF & $329.2^{\mathrm{ab}}$ & $335.8^{a}$ & $316.8^{b c}$ & $299.4^{c}$ & $267.8^{d}$ & $245.5^{\mathrm{e}}$ & $232.9^{\mathrm{e}}$ & $228.2^{\mathrm{e}}$ & $240.3^{e}$ & $233.6^{\mathrm{e}}$ & 6.25 & $<0.0001$ & $<0.0001$ & $<0.0001$ & $Q^{* *}$ \\
\hline Lignin (sa) & 47.0 & 54.5 & 46.1 & 47.4 & 35.9 & 27.2 & 26.0 & 25.8 & 27.6 & 19.3 & 2.86 & $<0.0001$ & 0.0060 & 0.3685 & $\mathrm{Q}^{*}$ \\
\hline
\end{tabular}

$(\mathrm{a}-\mathrm{g})$ Means in the same row with different superscripts differed $(\mathrm{P}<0.05)$

$1 \mathrm{DM}=$ dry matter; $\mathrm{CP}=$ crude protein; $\mathrm{NDF}=$ neutral detergent fiber; $\mathrm{ADF}=$ acid detergent fiber.

$2 \mathrm{~S}=$ silage; $\mathrm{L}=$ level of lime; $\mathrm{S} \times \mathrm{L}=$ interaction between factors.

${ }^{3} \mathrm{~L}=$ linear effect; $\mathrm{Q}=$ quadratic effect.

${ }^{*} \mathrm{P}<0.05$.

${ }^{* *} \mathrm{P}<0.01$

reduced ADF content by $61.4 \mathrm{~g} / \mathrm{kg}$ of DM in in natura sugarcane. However, lime had no effect on ADF content in burned sugarcane where values remained constant.

Although there was no interaction $(\mathrm{P}>0.05)$ between silage type and lime levels observed for lignin content, the in natura sugarcane exhibited greater $(\mathrm{P}<0.01)$ lignin content than burned sugarcane (Table 3 ). Overall, the greatest lime level $(20 \mathrm{~g} / \mathrm{kg})$ reduced the lignin content by 11.1 and $7.9 \mathrm{~g} / \mathrm{kg}$ of DM when applied on in natura and burned sugarcane compared to the respective untreated forages $(\mathrm{P}<0.05)$.

\subsubsection{Chemical composition and fermentation profile of in natura and burned sugarcane silages treated with different lime levels}

All variables were affected by the interaction $(\mathrm{P}<0.05)$ between silage type and lime levels, as shown in Table 4 . In natura silages had greater $(\mathrm{P}<0.01) \mathrm{DM}$ content than burned silages. However, in natura silages showed no change in DM content due to the lime application, whereas there was a quadratic increase in DM content in burned silages following lime application. Ash content exhibited a similar response; in other words, a quadratic increase $(P<0.01)$ in ash content following lime application was observed in both types of silage; in general, in natura silages had greater ash contents than burned silages.

A quadratic reduction ( $\mathrm{P}<0.01)$ in $\mathrm{CP}$ content was observed following lime application, regardless of silage type (Table 4). The greatest values of $\mathrm{CP}$ were observed in untreated in natura sugarcane or that treated with $10 \mathrm{~g} / \mathrm{kg}$ of lime and also in untreated burned silage.

Overall, in natura silages exhibited greater $(\mathrm{P}<0.01)$ NDF contents than burned silages (Table 4$)$. There was a quadratic reduction in NDF content with increased lime addition for both in natura and burned silages. If untreated silages are used as a baseline, lime reduced the NDF content by 143.2 and $265.1 \mathrm{~g} / \mathrm{kg}$ of DM when in natura silage was treated with $20 \mathrm{~g} / \mathrm{kg}$ lime and burned silage was treated with $10 \mathrm{~g} / \mathrm{kg}$, respectively. Likewise, these also were the most effective treatments for reducing $(\mathrm{P}<0.01)$ the $\mathrm{ADF}$ content. Addition of lime led to a marginal and quadratic decrease in lignin content $(\mathrm{P}<0.05)$ of in natura silage, and the application of 10 and $20 \mathrm{~g} / \mathrm{kg}$ of lime led to also a quadratic decrease in lignin content of burned silages.

All burned silages (except those treated with $5 \mathrm{~g} / \mathrm{kg}$ of lime) produced more $(\mathrm{P}<0.01)$ acetic acid than in natura silages revealing overall means of 47.0 vs. $25.6 \mathrm{~g} / \mathrm{kg}$ of DM, respectively (Table 4). Lime was more effective in increasing the production of acetic acid in in natura silages, but only when applied at great concentrations (15 and $20 \mathrm{~g} / \mathrm{kg}$ ).

There was a difference $(\mathrm{P}<0.01)$ in $\mathrm{pH}$ values between silage types only when great concentrations of lime $(15$ and $20 \mathrm{~g} / \mathrm{kg}$ ) were used in the treatment of silages; in natura silages had greater pH than burned silage (Table 4). However, as expected, $\mathrm{pH}$ cubically increased with an increase in the concentration of lime applied.

The gas losses of in natura silages quadratically increased $(\mathrm{P}<0.01)$ with lime addition; comparing untreated silage with those treated with 15 and $20 \mathrm{~g} / \mathrm{kg}$ of the additive, the increase was $44.8 \mathrm{~g} / \mathrm{kg}$ of DM (Table 4). Conversely, the use of lime quadratically reduced the gas losses in burned silages, especially when used at $10 \mathrm{~g} / \mathrm{kg}(103.5 \mathrm{~g} / \mathrm{kg}$ of DM less than untreated silage). Overall, lime addition quadratically decreased $(\mathrm{P}<0.01) \mathrm{DM}$ recovery in in natura silages (except the level of $5 \mathrm{~g} / \mathrm{kg}$, which increased this variable), whereas the opposite effect was observed for burned silages.

\subsubsection{Aerobic stability of in natura and burned sugarcane silages treated with different lime levels}

All variables related to aerobic stability were changed $(\mathrm{P}<0.05)$ by the interaction between silage type and lime levels, as shown in Table 4. Overall, lime had the desired effect on initial temperature, decreasing $(\mathrm{P}<0.05)$ this variable for both silage types, especially when great levels were used ( 15 and $20 \mathrm{~g} / \mathrm{kg}$ ). Similarly, the addition of lime reduced (P<0.05) the maximum temperature, particularly at $15 \mathrm{~g} / \mathrm{kg}$ for both silage types. Lesser $(\mathrm{P}<0.05)$ heating rates were observed when in natura and burned silages were treated with 15 and $20 \mathrm{~g} / \mathrm{kg}$ of lime, as well as for in natura silage treated with $10 \mathrm{~g} / \mathrm{kg}$. Similar results were found for SUM 5 and SUM $9(\mathrm{P}<0.01)$. Consequently, aerobic stability increased $(\mathrm{P}<0.01)$ when silages 
Table 4

Chemical composition, fermentation, and aerobic stability of in natura and burned sugarcane silages untreated or treated with lime ( $\mathrm{g} / \mathrm{kg}$ of sugarcane, on an as-is fresh matter basis).

\begin{tabular}{|c|c|c|c|c|c|c|c|c|c|c|c|c|c|c|c|c|}
\hline \multirow[t]{2}{*}{ Item $^{1}$} & \multicolumn{5}{|c|}{ In natura } & \multicolumn{5}{|l|}{ Burned } & \multirow[t]{2}{*}{ SEM } & \multicolumn{3}{|l|}{ P-value ${ }^{2}$} & \multicolumn{2}{|c|}{ Contrast $^{3}$} \\
\hline & 0 & 5 & 10 & 15 & 20 & 0 & 5 & 10 & 15 & 20 & & S & $\mathrm{L}$ & $\mathrm{S} \times \mathrm{L}$ & Main & Interaction \\
\hline \multicolumn{17}{|c|}{ Chemical composition, $\mathrm{g} / \mathrm{kg}$ of DM } \\
\hline $\mathrm{DM}, \mathrm{g} / \mathrm{kg}$ as fed & $272.7^{\mathrm{a}}$ & $269.8^{a}$ & $259.0^{\mathrm{a}}$ & $254.4^{\mathrm{a}}$ & $265.1^{\mathrm{a}}$ & $170.8^{\mathrm{d}}$ & $202.6^{c}$ & $214.9^{\mathrm{bc}}$ & $226.3^{b}$ & $212.2^{\mathrm{bc}}$ & 7.43 & $<0.0001$ & 0.2014 & 0.0007 & & Q \\
\hline Ash & $34.2^{\mathrm{f}}$ & $48.5^{\mathrm{e}}$ & $67.7^{\mathrm{d}}$ & $108.8^{\mathrm{b}}$ & $140.8^{\mathrm{a}}$ & $23.4^{\mathrm{g}}$ & $46.3^{e}$ & $65.7^{\mathrm{d}}$ & $96.1^{c}$ & $112.5^{\mathrm{b}}$ & 2.70 & $<0.0001$ & $<0.0001$ & 0.0007 & & $Q=$ \\
\hline $\mathrm{CP}$ & $42.5^{\mathrm{a}}$ & $38.6^{\mathrm{b}}$ & $43.6^{\mathrm{a}}$ & $38.1^{\mathrm{b}}$ & $37.3^{\mathrm{b}}$ & $43.2^{\mathrm{a}}$ & $34.5^{\mathrm{c}}$ & $29.7^{\mathrm{e}}$ & $30.8^{\text {de }}$ & $32.5^{\mathrm{d}}$ & 0.95 & $<0.0001$ & $<0.0001$ & $<0.0001$ & & $Q^{* *}$ \\
\hline NDF & $755.5^{\mathrm{a}}$ & $689.0^{\mathrm{bc}}$ & $708.7^{b}$ & $683.6^{c}$ & $612.3^{\mathrm{d}}$ & $681.1^{\mathrm{c}}$ & $506.7^{\mathrm{e}}$ & $416.0^{\mathrm{g}}$ & $440.9^{\mathrm{f}}$ & $443.8^{\mathrm{f}}$ & 10.04 & $<0.0001$ & $<0.0001$ & $<0.0001$ & & $\mathrm{Q}$ \\
\hline ADF & $426.2^{\mathrm{a}}$ & $386.7^{\mathrm{b}}$ & $402.4^{\mathrm{b}}$ & $416.3^{\mathrm{a}}$ & $392.9^{\mathrm{b}}$ & $428.3^{\mathrm{a}}$ & $310.1^{\mathrm{c}}$ & $277.0^{\mathrm{d}}$ & $302.5^{c}$ & $310.0^{c}$ & 6.03 & $<0.0001$ & $<0.0001$ & $<0.0001$ & & $\mathrm{Q}$ \\
\hline Lignin (sa) & $53.0^{\mathrm{ab}}$ & $46.7^{\mathrm{b}}$ & $48.7^{\mathrm{b}}$ & $56.4^{\mathrm{ab}}$ & $44.6^{\mathrm{b}}$ & $67.0^{\mathrm{a}}$ & $35.5^{\mathrm{bc}}$ & $24.6^{c}$ & $39.6^{\mathrm{bc}}$ & $29.2^{c}$ & 5.71 & 0.0077 & 0.0029 & 0.0393 & & $Q^{*}$ \\
\hline \multicolumn{17}{|c|}{ Fermentation process, $\mathrm{g} / \mathrm{kg}$ of DM } \\
\hline Acetic acid & $21.6^{\mathrm{c}}$ & $18.0^{\mathrm{c}}$ & $13.4^{\mathrm{d}}$ & $36.0^{\mathrm{b}}$ & $38.9^{\mathrm{b}}$ & $50.7^{\mathrm{a}}$ & $39.9^{\mathrm{b}}$ & $50.4^{\mathrm{a}}$ & $48.7^{\mathrm{a}}$ & $45.2^{\mathrm{ab}}$ & 2.63 & $<0.0001$ & $<0.0001$ & $<0.0001$ & & Q \\
\hline $\mathrm{pH}$ & $3.42^{\mathrm{f}}$ & $3.66^{\mathrm{e}}$ & $4.18^{\mathrm{d}}$ & $5.52^{\mathrm{b}}$ & $5.98^{\mathrm{a}}$ & $3.31^{\mathrm{f}}$ & $3.65^{\mathrm{e}}$ & $4.11^{\mathrm{d}}$ & $4.48^{\mathrm{c}}$ & $4.58^{\mathrm{c}}$ & 0.05 & $<0.0001$ & $<0.0001$ & $<0.0001$ & & $\mathrm{C}^{* *}$ \\
\hline Gas losses & $149.2^{\text {cd }}$ & $83.2^{\mathrm{f}}$ & $156.6^{c}$ & $227.1^{\mathrm{b}}$ & $238.4^{\mathrm{b}}$ & $272.2^{\mathrm{a}}$ & $122.1^{\text {de }}$ & $111.9^{\mathrm{e}}$ & $149.4^{\text {de }}$ & $145.8^{\text {de }}$ & 10.80 & 0.1028 & $<0.0001$ & $<0.0001$ & & $\mathrm{Q}^{*}$ \\
\hline DM recovery & $849.5^{\mathrm{cd}}$ & $912.0^{\mathrm{a}}$ & $842.1^{\mathrm{d}}$ & $771.6^{\mathrm{e}}$ & $760.3^{e}$ & $727.0^{f}$ & $877.4^{\mathrm{bc}}$ & $887.8^{\mathrm{b}}$ & $850.1^{\mathrm{bc}}$ & $853.6^{\mathrm{bc}}$ & 10.96 & 0.1028 & $<0.0001$ & $<0.0001$ & & $Q^{* *}$ \\
\hline \multicolumn{17}{|l|}{ Aerobic exposure } \\
\hline Initial $\mathrm{T},{ }^{\circ} \mathrm{C}$ & $25.3^{\mathrm{a}}$ & $24.5^{\mathrm{bc}}$ & $25.5^{\mathrm{a}}$ & $24.8^{\mathrm{b}}$ & $24.8^{\mathrm{b}}$ & $24.8^{\mathrm{b}}$ & $24.5^{\mathrm{bc}}$ & $24.3^{\mathrm{c}}$ & $24.2^{\mathrm{c}}$ & $24.3^{c}$ & 0.14 & $<0.0001$ & 0.0016 & 0.0220 & & $\mathrm{C}^{* * *}$ \\
\hline Maximum $\mathrm{T},{ }^{\circ} \mathrm{C}$ & $42.2^{\mathrm{a}}$ & $40.8^{\mathrm{a}}$ & $30.8^{\mathrm{bc}}$ & $29.5^{c}$ & $30.2^{\mathrm{c}}$ & $42.2^{\mathrm{a}}$ & $41.0^{\mathrm{a}}$ & $37.7^{\mathrm{b}}$ & $29.8^{\mathrm{c}}$ & $34.5^{\mathrm{b}}$ & 1.05 & 0.0033 & $<0.0001$ & 0.0196 & & $C^{*}$ \\
\hline Heating rate, ${ }^{\circ} \mathrm{C} / \mathrm{h}$ & $0.18^{\mathrm{bc}}$ & $0.16^{c}$ & $0.05^{\mathrm{d}}$ & $0.05^{\mathrm{d}}$ & $0.06^{\mathrm{d}}$ & $0.22^{\mathrm{ab}}$ & $0.27^{a}$ & $0.13^{c}$ & $0.04^{\mathrm{d}}$ & $0.07^{\mathrm{d}}$ & 0.02 & 0.0008 & $<0.0001$ & 0.0252 & & $\mathrm{C}^{*}$ \\
\hline SUM $5,{ }^{\circ} C^{4}$ & $15.0^{c}$ & $11.4^{\mathrm{d}}$ & $-0.8^{\mathrm{e}}$ & $-5.1^{\mathrm{ef}}$ & $-0.2^{\mathrm{e}}$ & $29.5^{\mathrm{a}}$ & $24.1^{\mathrm{b}}$ & $-0.2^{\mathrm{e}}$ & $-7.8^{\mathrm{f}}$ & $-6.6^{\mathrm{f}}$ & 1.67 & 0.0033 & $<0.0001$ & $<0.0001$ & & $L^{* *}$ \\
\hline SUM $9,{ }^{\circ} \mathrm{C}^{4}$ & $21.9^{\mathrm{bc}}$ & $20.8^{\mathrm{bc}}$ & $10.3^{c}$ & $-8.4^{\mathrm{d}}$ & $0.1^{c}$ & $58.7^{\mathrm{a}}$ & $38.7^{\mathrm{b}}$ & $20.8^{\mathrm{bc}}$ & $-10.0^{\mathrm{d}}$ & $4.4^{c}$ & 4.01 & 0.0003 & $<0.0001$ & $<0.0001$ & & $\mathrm{~L}^{* *}$ \\
\hline Aerobic stability, h & $75.0^{c}$ & $83.0^{c}$ & $194.5^{\mathrm{a}}$ & $214.0^{\mathrm{a}}$ & $214.0^{\mathrm{a}}$ & $36.3^{\mathrm{d}}$ & $49.0^{\mathrm{d}}$ & $95.0^{c}$ & $204.3^{\mathrm{a}}$ & $153.0^{\mathrm{b}}$ & 8.12 & $<0.0001$ & $<0.0001$ & 0.0009 & & $\mathrm{C}^{* * *}$ \\
\hline
\end{tabular}

(a-g) Means in the same row with different superscripts differed $(\mathrm{P}<0.05)$.

$1 \mathrm{DM}=$ dry matter; $\mathrm{CP}=$ crude protein; $\mathrm{NDF}=$ neutral detergent fiber; $\mathrm{ADF}=$ acid detergent fiber.

$2 \mathrm{~S}=$ silage; $\mathrm{L}=$ level of lime; $\mathrm{S} \times \mathrm{L}=$ interaction between factors.

${ }^{3} \mathrm{~L}=$ linear effect; $\mathrm{Q}=$ quadratic effect; $\mathrm{C}=$ cubic effect.

${ }^{4}$ Sum of the difference of temperatures between silages and ambient after 5 and $9 \mathrm{~d}$ of aerobic exposure.

* $\mathrm{P}<0.05$.

** $\mathrm{P}<0.01$

${ }^{* * *} \mathrm{P}<0.10$. 

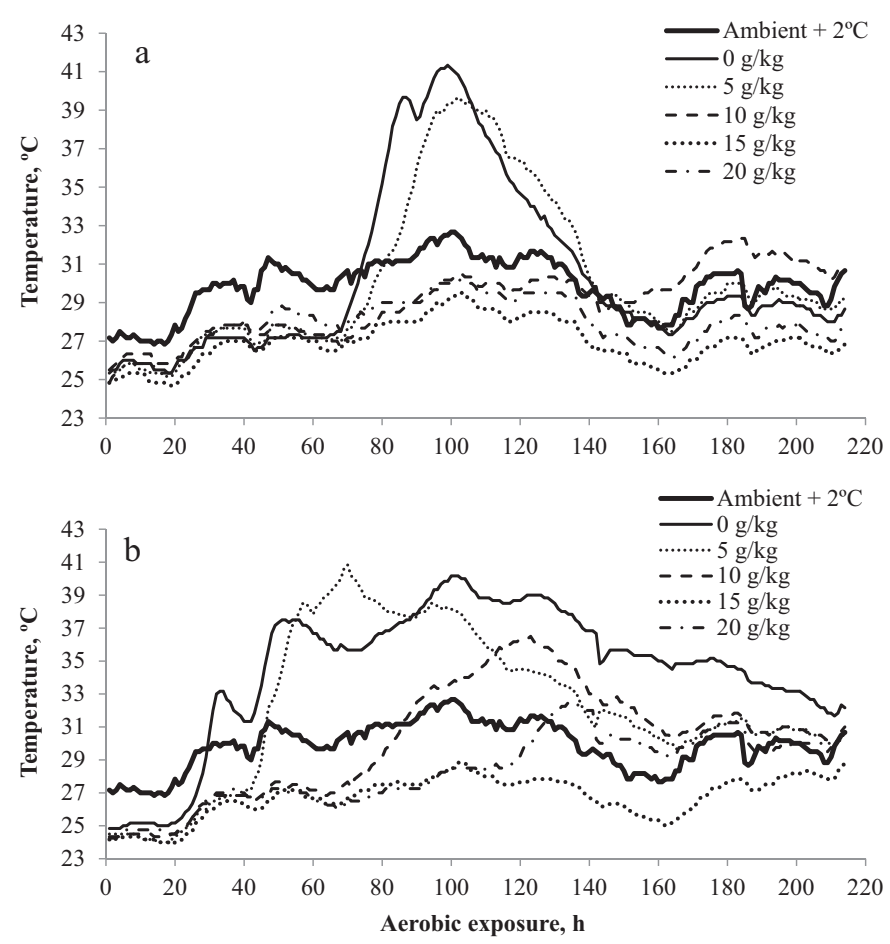

Fig. 3. Temperature of in natura (a) and burned (b) silages either untreated or treated with lime ( $\mathrm{g} / \mathrm{kg}$ of sugarcane, on an as-is fresh matter basis) during aerobic exposure.

were treated with great levels of lime. In natura silages treated with 10,15 , and $20 \mathrm{~g} / \mathrm{kg}$ lime and burned silage treated with $15 \mathrm{~g} / \mathrm{kg}$ lime exhibited great aerobic stability ( $>8 \mathrm{~d}$ ). Conversely, untreated silages or those treated with less levels of lime exhibited large peaks of temperature during aerobic exposure (Fig. 3).

During aerobic exposure, $\mathrm{pH}$ was affected by interactions $(\mathrm{P}<0.01)$ among silage type, lime levels, and time exposed to oxygen (Fig. 4). For the first 3 days of aerobic exposure, both silages exhibited greater pH values when treated with 15 and $20 \mathrm{~g} / \mathrm{kg}$ of lime. However, after day 3, the most effective treatments were the application of $10 \mathrm{and} 15 \mathrm{~g} / \mathrm{kg}$ of lime for in natura and burned silages, respectively.

\section{Discussion}

\subsection{Trial I}

Prior to ensiling, the burned sugarcane had a reduction in sucrose content with increases in redox sugars over time while remained in the field likely by invertase activity. Invertase activity can convert sucrose into glucose and fructose during the accumulation of sucrose in tissues of sugarcane (Whittaker and Botha, 1997), and its activity may increase in great temperatures (e.g., sugarcane burning). This hypothesis could explain why sugarcane purity also decreased, taking into consideration the quantity of sucrose in relation to total solids.

Even with cubic effect, we observed that delay in post-burning ensiling increased yeast population in sugarcane likely by exudation or escape of sugars or both, caused by burning, which destroy wax layer that enfolds the cell-wall and cause cracks in the stalk (Bernardes et al., 2007). A previous study also reported increases of yeast population in burned sugarcane throughout the 14-d post-burning (Roth et al., 2010). In our study, increases in yeast population may be the cause of the increased fiber fraction in sugarcane that remained in the field for many days post-burning. Yeasts use water-soluble carbohydrates (WSC) as the main substrate for their growth; in turn, the fiber fraction increases via the concentration effect (Rabelo et al., 2014). However, the increases in NDF content unaffected IVOMD of burned sugarcane for unknown reasons.

DM content also increased according to the length of time the sugarcane remained in the field post-burning likely because the increased yeasts activity, and water loss caused by burning. CP decreased up to 10-d post-burning and increased after this time. Yeasts and other microorganisms are composed of protein, and certainly their overgrowth after 10-d post-burning contributed to increase the $\mathrm{CP}$ content of sugarcane.

When the silos were opened, great amounts of acetic acid was observed in the 1- and 30-d post-burning silages likely arising the better conditions found by LAB population to growth. Acetic acid is a powerful antifungal agent (Danner et al., 2003) capable of inhibiting yeast and reducing ethanol formation and DM loss during silage fermentation (Ávila et al., 2009). 

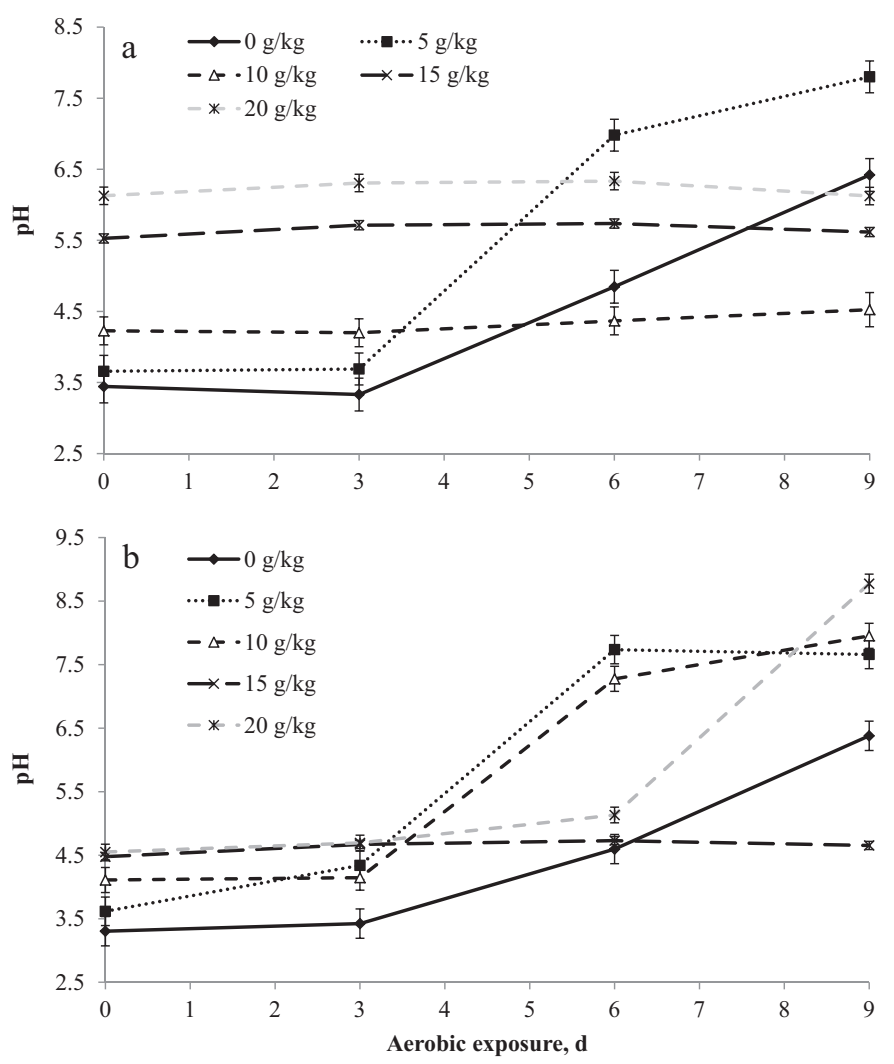

Fig. 4. $\mathrm{pH}$ values of in natura (a) and burned (b) silages either untreated or treated with lime (g/kg of sugarcane, on an as-is fresh matter basis) during aerobic exposure (effect of silage type: $\mathrm{P}>0.10$; lime: $\mathrm{P}<0.01$; aerobic exposure days: $\mathrm{P}<0.01$; interaction among the factors: $\mathrm{P}<0.01$ ).

There was not a clear effect of post-burning days on DM recovery (cubic effect); however, despite of the greater acetic acid concentration, 1 - and 30-d post-burning silages did not have greater DM recovery. The 15-d post-burning silage had the greatest DM recovery, possibly due to decreased yeast activity because this silage had less sugar contents compared to those that remained in the field for fewer days post-burning. Conversely, all silages had low DM recovery ( $<750 \mathrm{~g} / \mathrm{kg}$ of DM). Although all silages exhibited low $\mathrm{pH}(<3.45)$, this does not ensure a desirable fermentation, as yeasts are able to growth in a wide range of $\mathrm{pH}$, from 2.5 to 8.5 (Orij et al., 2011). The main metabolic pathway of yeast uses pyruvate decarboxylase acetaldehyde and the posterior reduction of acetaldehyde into ethanol occurs (Rooke and Hatfield, 2003), resulting in DM losses of $489 \mathrm{~g} / \mathrm{kg}$ as fed during fermentation (McDonald et al., 1991). Indeed, a low DM recovery has been reported in burned silages because the intense yeasts activity (Roth et al., 2010; Siqueira et al., 2010).

The great DM losses also explain the reduction in DM content of silages compared to sugarcane before ensiling in our study, a response previously reported by Siqueira et al. (2007). Similarly, ash, CP, NDF, and ADF increased in silages compared to forage. Fermentation process occurs by converting of soluble sugars to organic acids, and an increase in other compounds is expected due to the concentration effect (Rabelo et al., 2014).

Furthermore, lignin content of burned silages linearly increased with increased post-burning days likely as a response for the yeasts overgrowth. The 1-, 5-, and 10-d burned silages had lesser lignin content when compared with those produced with sugarcanes that remained a long time in the field post-burning. Thus, the lesser lignin contents probably explain the quadratic response observed for the coefficients of IVOMD, where burned silages up to 10-d post-burning had a greater digestibility. The negative effect of lignin on digestibility has been previously documented (Jung and Allen, 1995). However, all silages had low digestibility (435-490 g/kg of organic matter), and our data are in accordance with previous studies (Roth et al., 2010; Siqueira et al., 2011b), which also reported a low digestibility of burned sugarcane silages.

The silage produced from sugarcane that remained in the field 15-d post-burning had the greatest maximum temperature likely by the greater DM recovery. Silages with great DM recovery often exhibit a desirable fermentation pattern (i.e., greater production of lactic acid and preservation of residual WSC) and can have lesser aerobic stability (McDonald et al., 1991), as confirmed in this study. Aerobic exposure of silage leads to extensive oxidization of WSC driven by the growth of epiphytic microorganisms, especially yeasts, with increases in temperature and decreases in the nutritive value of feed (Kung and Stanley, 1982; Wilkinson and Davies, 2012).

The 1-d post-burning silage exhibited the greatest production of acetic acid; however, this silage had low aerobic stability $(<15 \mathrm{~h})$. Although acetic acid has been strongly related to enhance aerobic stability (Danner et al., 2003), yeasts are able to 
growth in a wide range of conditions (Orij et al., 2011; Pahlow et al., 2003). Conversely, the 20-d post-burning silage showed the greatest aerobic stability, as well as the least $\mathrm{pH}$ after $6 \mathrm{~d}$ of aerobic exposure. This is probably due to lesser sugar content during ensiling compared to those silages prepared with sugarcane that remained in the field for a shorter time post-burning. The lesser $\mathrm{pH}$ found in the 20-d post-burning silage during aerobic exposure is likely associated with the lesser yeasts growth. Yeasts are able to use lactic acid as a substrate, causing an increase in pH values, especially when the $\mathrm{pH}$ is greater than 4.5, favoring the growth of other spoilage microorganisms (Wilkinson and Davies, 2012). Consequently, there is an important reduction in the nutritive value of silage.

Overall, although ensiling of burned sugarcane between 10- to 15-d post-burning revealed a greater DM recovery, in our study there was not a clear effect of post-burning days on the fermentation patterns and aerobic stability of silages, since a cubic response occurred for many variables. Likewise, Roth et al. (2010) found inconsistent results in silages produced with burned sugarcane throughout the 14-d post burning. Brazil is the largest producer of sugarcane in the world (FAO, 2015) and accidental fire still occurs in the field, but the quality of burned sugarcane silage has been few investigated, and further studies are necessary to understand the impact of burning on it.

\subsection{Trial II}

In natura sugarcane had greater DM, CP, and fiber content than burned sugarcane, both before and after ensiling. During burning, straw is the primary part of the plant affected; straw has great DM and fiber content and a less amount of CP. The loss of straw, which comprises mostly senescent leaves that contain great NDF content, during burning, explains our results. A previous study also reported similar results in in natura and burned sugarcane (Siqueira et al., 2010).

Ash content quadratically increased in in natura and burned sugarcane before and after ensiling by lime addition, once this additive has great ash content; however, this response was not translated in marked increases in DM content likely by water loss caused by heating of sugarcane when lime was added. Calcium oxide in contact with water produces an alkaline compound $\left(\mathrm{CaO}+\mathrm{H}_{2} \mathrm{O} \rightarrow \mathrm{Ca}(\mathrm{OH})_{2}+\right.$ heat $)$, and considerable quantity of heat $(15,300 \mathrm{cal} / \mathrm{mol})$ may be produced. In addition, $\mathrm{CP}$ quadratically reduced with increasing additions of lime, which is probably due to a dilution effect.

Overall, the fiber fraction quadratically decreased by lime addition, and the greatest levels (i.e., $15 \mathrm{and} 20 \mathrm{~g} / \mathrm{kg}$ ) reflected in lesser values. Alkaline additives have been used in order to reduce the fiber fraction and increase the fiber digestibility, or both (Santos et al., 2009). Lime often has the capacity to expand the fiber (hydrolysis), causing a rupture in the ester linkages between lignin and hemicellulose, and breaking the hydrogen linkages between cellulose and hemicellulose (Klopfenstein, 1980). Thus, our results are in accordance with the chemical role played by lime.

Despite of cubic effect, lime addition increased the $\mathrm{pH}$ values for both silages; however, $\mathrm{pH}$ increased more strongly in in natura silages than burned silages. Increases in $\mathrm{pH}$ values are expected because the application of lime to sugarcane causes hydration of calcium oxide and production of alkali (Daniel et al., 2013).

Acetic acid concentration increased in in natura silages due to the application of lime. If lime is able to break linkages between lignin and hemicellulose (Klopfenstein, 1980), an increase in the production of organic acids is expected (verified for acetic acid in the present study) because LAB metabolize nonstructural carbohydrates into organic acids (Rooke and Hatfield, 2003). Moreover, LAB (mainly heterofermentative LAB) probably had greater activity in elevated-pH conditions, since these microorganisms growth slowly when $\mathrm{pH}$ values are below 3.5 (McDonald et al., 1991). A quadratic response was observed for gas losses, and great levels of lime (15 and $20 \mathrm{~g} / \mathrm{kg}$ ) led to an increase in gas losses in in natura silages, resulting in lesser DM recovery (except for silage treated at $5 \mathrm{~g} / \mathrm{kg}$ ). This may be explained by an increase in acetic acid production because there is production of $\mathrm{CO}_{2}$ in heterolactic pathway caused by the fermentation of WSC, and this via is less efficient than the homolactic pathway in DM recovery (Muck, 2010). Additionally, the reduction in DM recovery in in natura silages with increased lime application likely suggest greater ethanol production (not measured in our study), which is the major problem in sugarcane silages (Kung and Stanley, 1982). Greater DM recovery is not always observed when using great doses of alkaline additives (Pedroso et al., 2007), which is consistent with our study.

An opposite response in DM recovery due to the lime addition was observed in burned silages. Lime quadratically increased DM recovery in burned silages due to the lesser gas losses. Yeasts use WSC producing ethanol and $\mathrm{CO}_{2}(\mathrm{McDonald}$ et al., 1991). A great and positive correlation $\left(\mathrm{R}^{2}=0.89\right)$ between ethanol and gas losses has been observed (Pedroso et al., 2005). In this case, the great production of $\mathrm{CO}_{2}$ is likely due to the low efficient metabolic pathway of yeasts, once acetic acid level is no longer increased by the application of lime. Our results are consistent with the greater DM recovery observed in other cultivars of sugarcane ensiled with lime (Santos et al., 2008).

Application of lime $(>10 \mathrm{~g} / \mathrm{kg})$ reduced the heating rate in silages, thereby these silages exhibited a long period of stability when aerobically exposed. Lime possesses antifungal properties, and the inhibition of spoilage microorganisms must be related to changes in the osmotic potential of silage that reduce the growth of yeast (Pahlow et al., 2003). The positive effect of lime to enhance aerobic stability has been reported in several studies (Amaral et al., 2009; Balieiro Neto et al., 2009; Rezende et al., 2011).

Succession of yeast species occurs from the anaerobic phase to the aerobic phase when silos are opened (Pahlow et al., 2003), and this process continues during the aerobic exposure phase (Pitt et al., 1991). A majority of yeast species that are active during oxygen exposure are the same epiphytic species found in the forage before ensiling (Pahlow et al., 2003). Increased aerobic stability should be expected in burned sugarcane because heat could interfere with the succession process (Siqueira et al., 2010). However, taking into consideration the overall mean, the in natura silages had great stability compared 
to burned silages (156.1 vs. $107.5 \mathrm{~h}$, respectively). Our hypothesis is that burned sugarcane probably had greater production of lactic acid (which was not measured in this study) suggested by the great DM recovery. Lactic acid no has an antifungal effect per se (Moon, 1983), and can be largely used as a substrate for the growth of yeast (Wilkinson and Davies, 2012). Thus, better fermentation usually results in low aerobic stability of silages (McDonald et al., 1991).

Linear decreases in accumulated temperature of in natura and burned silages were observed; however, lime addition had a cubic effect on aerobic stability. Different lime levels led to inconsistent results, mainly when considered the different types of sugarcane (in natura and burned). Conversely, the greater levels of lime ( 15 and $20 \mathrm{~g} / \mathrm{kg}$ ) seems to be consistent to enhance aerobic stability of silages, regardless of sugarcane type.

\section{Conclusions}

The impact of post-burning days on the characteristics of burned silage was not clear, and further studies should be considered. However, considering the approach in which this study was carried out, if a sugarcane field is burned accidentally, the farmers have $10-15 \mathrm{~d}$ time period to ensile the forage so that the digestibility and conservation of nutrients may be maximized.

Lime consistently improved DM recovery in burned silages. The greater levels of lime (15 and $20 \mathrm{~g} / \mathrm{kg}$ ) reduced fiber fraction and enhanced aerobic stability for both in natura and burned silages. In summary, lime may be used as an additive for both in natura and burned silages since in greater levels.

\section{Acknowledgement}

The authors wish to express their appreciation to the Sao Paulo Research Foundation (FAPESP) for their financial support.

\section{Appendix A. Supplementary data}

Supplementary data associated with this article can be found, in the online version, at http://dx.doi.org/10.1016/j.anifeedsci.2016.03.010.

\section{References}

Ávila, C.L.S., Pinto, J.C., Figueiredo, H.C.P., Schwan, R.F., 2009. Effects of an indigenous and a commercial Lactobacillus buchneri strain on quality of sugar cane silage. Grass Forage Sci. 64, 384-394.

Amaral, R.C., Pires, A.V., Susin, I., Nussio, L.G., Ferreira, E.M., Gentil, R.S., 2009. Cana-de-açúcar in natura ou ensilada com e sem aditivos químicos: estabilidade aeróbia dos volumosos e das rações. Braz. J. Anim. Sci. 38, 1857-1864.

Association of Official Analytical Chemist, AOAC, 1996. Official Methods of Analysis, 16 ed. AOAC, Washington DC, USA.

Balieiro Neto, G., Ferrari Junior, E., Nogueira, J.R., Possenti, R., Paulino, V.T., Bueno, M.S., 2009. Perdas fermentativas, composição química, estabilidade aeróbia e digestibilidade aparente de silagem de cana-de-açúcar com aditivos químico e microbiano. Pesq. Agropec. Bras. 44, 621-630.

Bernardes, T.F., Rêgo, A.C., 2014. Study on the practices of silage production and utilization on Brazilian dairy farms. J. Dairy Sci. 97, $1852-1861$.

Bernardes, T.F., Reis, R.A., Siqueira, G.R., Berchielli, T.T., Coan, R.M., 2007. Avaliação da queima e da adição de milho desintegrado com palha e sabugo na ensilagem de cana-de-açúcar. Braz. J. Anim. Sci. 36, 269-275.

Bovi, R., Serra, G.E., 1999. Impurezas fibrosas da cana-de-açúcar e parâmetros tecnológicos do caldo extraído. Sci. Agric. 56, 885-896.

Cavali, J., Pereira, O.G., Valadares Filho, S.C., Santos, E.M., Carvalho, G.G.P., Santos, M.V., Porto, M.O., Rodrigues, J.F.H., 2010. Bromatological and microbiological characteristics of sugarcane silages treated with lime. Braz. J. Anim. Sci. 39, 1398-1408.

Daniel, J.L.P., Santos, M.C., Zopollatto, M., Huhtanen, P., Nussio, L.G., 2013. A data-analysis of lime addition on the nutritive value of sugarcane in Brazil. Anim. Feed Sci. Technol. 184, 17-23.

Danner, H., Holzer, M., Mayrhuber, E., Braun, R., 2003. Acetic acid increases stability of silage under aerobic conditions. Appl. Environ. Microbiol. 69, 562-567.

FAO, 2015. World Programme for the Census of Agriculture: yield. Food and Agriculture Organization of the United Nations, Rome, Italy.

Jung, H.G., Allen, M.S., 1995. Characteristics of plant cell walls affecting intake and digestibility of forages by ruminants. J. Anim. Sci. 73, $2774-2790$.

Klopfenstein, T.J., 1980. Increasing the nutritive value of crop residues by chemical treatments, in: upgrading residues and products for animals. CRC Press, Boca Raton, pp. 40-60.

Kung Jr., L., Stanley, R.W., 1982. Effect of stage of maturity on the nutritive value of whole-plant sugarcane preserved as silage. J. Anim. Sci. 54, 689-696.

Kung Jr., L., Grieve, D.B., Thomas, J.W., Huber, J.T., 1984. Added ammonia or microbial inoculant for fermentation and nitrogenous compounds of alfalfa ensiled at various percents of dry matter. J. Dairy Sci. 67, 299-306.

Kurtman, C.P., Fell, J.W., 1998. The Yeast: a Taxonomic Study. Elsevier, Amsterdam.

Marten, G.C., Barnes, R.F., 1979. Prediction of energy digestibility of forages with in vitro rumen fermentation and fungal enzymes systems. In: Pigden, W.J., Balch, C.C., Graham, M. (Eds.), Standardization of Analytical Methodology for Feeds. International Development Research Center, Ottawa, Canada, pp. 61-128.

Mauricio, R.M., Mould, F.L., Dhanoa, M.S., Owen, E., Channa, K.S., Theodorou, M.K., 1999. A semi-automated in vitro gas production technique for ruminant feedstuff evaluation. Anim. Feed Sci. Technol. 79, 321-330.

McDonald, P., Henderson, A.R., Heron, S.J.E., 1991. The Biochemistry of Silage., 2nd ed. Chalcombe Publ., Abersytwyth, U.K.

Menke, K.H., Steingass, H., 1988. Estimation of the energetic feed value obtained from chemical analysis and in vitro gas production using rumen fluid. Anim. Res. Dev. 28, 7-55.

Millen, D.D., Pacheco, R.D.L., Arrigoni, M.D.B., Galyean, M.L., Vasconcelos, J.T., 2009. A snapshot of management practices and nutritional recommendations used by feedlot nutritionists in Brazil. J. Anim. Sci. 87, 3427-3439.

Moon, N., 1983. Inhibition of the growth of acid tolerant yeasts by acetate, lactate and propionate and their synergistic mixtures. J. Appl. Bacteriol. 55, 453-460.

Moran, J.P., Weinberg, Z.G., Ashbell, G., Hen, Y., Owen, T.R., 1996. A comparison of two methods for the evaluation of the aerobic stability of whole crop wheat silage. In: Proc 11th Int. Silage Conf., Univ. of Wales, Aberystwyth, UK, pp. 162-163.

Muck, R.E., 2010. Silage microbiology and its control through additives. Braz. J. Anim. Sci. 39, 183-191. 
O’Kiely, P., 1999. Maximizing Output of Beef within Cost Efficient, Environmentally Compatible Forage Conservation Systems. Grange Research Centre, Dunsany.

Orij, R., Brul, S., Smits, G.J., 2011. Intracellular pH is a tightly controlled signal in yeast. Biochim. Biophys. Acta 1810, $933-944$.

Pahlow, G., Muck, R.E., Driehuis, F., Oude-Elferink, S.J.W.H., Spoelstra, S.F., 2003. Microbiology of ensiling. In: Buxton, D.R., Muck, R.E., Harrison, J.H. (Eds.) Silage Science and Technology. American Society of Agronomy, Madison, WI, pp. 31-93.

Pedroso, A.F., Nussio, L.G., Paziani, S.F., Loures, D.R.S., Igarasi, M.S., Coelho, R.M., Packer, I.H., Horii, J., Gomes, L.H., 2005. Fermentation and epiphytic microflora dynamics in sugar cane silage. Sci. Agric. 62, 427-432.

Pedroso, A.F., Nussio, L.G., Loures, D.R.S., Paziani, S.F., Igarasi, M.S., Coelho, R.M., Horii, J., Rodrigues, A.A., 2007. Efeito do tratamento com aditivos químicos e inoculantes bacterianos nas perdas e na qualidade de silagens de cana-de-açúcar. Braz. J. Anim. Sci. 36, 558-564.

Pell, A.N., Schofield, P., 1993. Computerized monitoring of gas production to measure forage digestion in vitro. J. Dairy Sci. 76 , $1063-1073$.

Pitt, R.E., Muck, R.E., Pickering, N.B., 1991. A model of aerobic fungal growth in silage. 2. Aerobic stability. Grass Forage Sci 46, $301-312$.

Rabelo, C.H.S., Costa, A.P., Rezende, A.V., Härter, C.J., Florentino, L.A., Rabelo, F.H.S., 2014. What is the best additive to use at the ensiling of sugarcane SP81-3250? Anim. Prod. Sci. 54, 1682-1686.

Rezende, A.V., Rabelo, C.H.S., Rabelo, F.H.S., Nogueira, D.A., Faria Jr., D.C.N.A., Barbosa, L.A., 2011. Perdas fermentativas e estabilidade aeróbia de silagens de cana-de-açúcar tratadas com cal virgem e cloreto de sódio. Braz. J. Anim. Sci. 40, 739-746.

Robertson, J.B., Van Soest, P.J., 1981. The detergent system of analysis and its application to human foods. In: James, W.P.T., Theander, O. (Eds.), The Analysis of Dietary Fiber in Food. Marcel Dekker, New York, pp. 123-158.

Rooke, J.A., Hatfield, R.D., 2003. Biochemistry of ensiling. In: Buxton, D.R., Muck, R.E., Harrison, J.H. (Eds.), Silage Science and Technology. American Society of Agronomy, Madison, WI, pp. 95-140.

Roth, A.P.T.P., Reis, R.A., Siqueira, G.R., Roth, M.T.P., Resende, F.D., Monteiro, R.R., 2010. Sugarcane silage production treated with additives at different times post burning. Braz. J. Anim. Sci. 39, 88-96.

Ruppel, K.A., Pitt, R.E., Chase, L.E., Galton, D.M., 1995. Bunker silo management and its relationship to forage preservation on dairy farms. J. Dairy Sci. 78, $141-153$.

Santos, M.C., Nussio, L.G., Mourão, G.B., Schmidt, P., Mari, L.J., Ribeiro, J.L., 2008. Influência da utilização de aditivos químicos no perfil da fermentação, no valor nutritivo e nas perdas de silagens de cana-de-açúcar. Braz. J. Anim. Sci. 37, 1555-1563.

Santos, M.C., Nussio, L.G., Mourão, G.B., Schmidt, P., Mari, L.J., Ribeiro, J.L., Queiroz, O.C.M., Zopollatto, M., Sousa, D.P., Sarturi, J.O., Toledo Filho, S.G., 2009. Nutritive value of sugarcane silage treated with chemical additives. Sci. Agric. 66, 159-163.

Siqueira, G.R., Reis, R.A., Schocken-Iturrino, R.P., Pires, A.J.V., Bernardes, T.F., Amaral, R.C., 2007. Perdas de silagens de cana-de-açúcar tratadas com aditivos químicos e bacterianos. Braz. J. Anim. Sci. 36, 2000-2009.

Siqueira, G.R., Reis, R.A., Schocken-Iturrino, R.P., Pires, A.J.V., Bernardes, T.F., Roth, M.T.P., 2010. Queima e aditivos químicos e bacterianos na ensilagem de cana-de-açúcar. Braz. J. Anim. Sci. 39, 103-112.

Siqueira, G.R., Schocken-Iturrino, R.P., Roth, A.P.T.P., Domingues, F.N., Ferraudo, A.S., Reis, R.A., 2011a. Óxido de cálcio e Lactobacillus buchneri NCIMB 40788 na ensilagem de cana-de-açúcar in natura ou queimada. Braz. J. Anim. Sci. 40, 2347-2358.

Siqueira, G.R., Reis, R.A., Schocken-Iturrino, R.P., Roth, A.P.T.P., Roth, M.T.P., Resende, F.D., 2011b. Perfil fermentativo de silagens de cana-de-açúcar in natura ou queimada e tratadas ou não com Lactobacillus buchneri. Braz. J. Anim. Sci. 40, 1651-1661.

Tilley, J.M.A., Terry, R.A., 1963. A two stage technique for the in vitro digestion of forage crops. Grass Forage Sci. 18, 104-111.

Van Soest, P., 1994. Nutritional Ecology of the Ruminant, 2nd ed. Cornell University Press, Ithaca.

Whittaker, A., Botha, F.C., 1997. Carbon partitioning during sucrose accumulation in sugarcane internodal tissue. Plant Physiol. 115, 1651-1659.

Wilkinson, J.M., Davies, D.R., 2012. The aerobic stability of silage: key findings and recent developments. Grass Forage Sci. 68, $1-19$. 